\title{
Note from the New Editor-in-Chief
}

It is a great honour and privilege to succeed Sir Arnold Burgen as Editor-in-Chief of the European Review. For many years Sir Arnold has tirelessly worked to promote the interests of the Review, and to make it into the splendid journal it now is. I fully intend to continue his work, to maintain the high quality of the Review, and to go on building its strength. I thank the President and Board of the Academia Europaea for entrusting the Review to me, and the Review's present co-editor, Henk Wesseling, for his willingness to continue working with me on the upcoming issues. I also want to assure all of the Review's collaborators and contributors that I will do my utmost to follow the example set by Sir Arnold, and to make the Review a hospitable meeting ground for ideas and insights put forth by the members of the Academia as well as for the academic community at large. In this vein I want to invite all Academia members to consider submitting whatever articles they may deem suitable for publication in the European Review.

Theo D'haen 